\title{
The UN Global Compact as a Soft Law Business Regulatory Mechanism Advancing Corporate Responsibility Towards Business Sustainability and Sustainable Development Worldwide
}

\author{
Edward T. Bristol-Alagbariya* \\ Associate Dean \& Senior Multidisciplinary Lecturer, Faculty of Law, University of Port Harcourt, NIGERIA; \\ Affiliate Visiting Fellow, University of Aberdeen, UNITED KINGDOM; and Visiting Research Fellow, Centre \\ for Energy, Petroleum \& Mineral Law and Policy (CEPMLP), Graduate School of Natural Resources Law, \\ Policy \& Management, University of Dundee, Scotland, UNITED KINGDOM
}

\begin{abstract}
This study arises from a previous work by the author captioned 'Sustainable Development: A Soft Law Concept Transforming SD-Oriented Initiatives of the UN System into Hard Law Instruments in UN Member-states and Promoting Partnerships around the Globe'. The previous work demonstrates that there are various examples of SD-oriented partnership mechanisms associated with business sustainability, environmental protection, good public sector governance (good governance: GG) and sustainable development (SD), of which the UN Global Compact is one. Thus, the aim of this study is to examine the UN Global Compact as a soft law SD-oriented mechanism fostering and enhancing business sustainability and overall SD, where business organisations that are enlisted to participate at the Compact are operating. The study arrives at the finding that for about two decades of its existence, the UN Global Compact is taking corporate responsibility from the fringes to the mainstream and uniting business towards a better, fairer, kinder, more just, sustainable and peaceful world on Planet Earth. A cardinal business sustainability initiative of the Global Compact is its ten principles in the areas of human rights, labour, environment and anti-corruption. The study arrives at the finding that the Compact is an inspirational guide on these principles, on the platform of which companies enlisted to participate at the Global Compact are, at a minimum, required to operate in ways that align their operations and strategies to conform to, and thereby promote and actualise development partnerships arising from their operations towards business sustainability and allembracing SD. This is demonstrated by the thirteen examples of good Corporate Social Responsibility (CSR) performances-in-action discussed herein and numerous other exemplary cases of CSR being actualised in the nooks and crannies of the world by businesses enlisted into the Global Compact framework. The study recommends that more and more companies (businesses) should enlist to participate at the Global Compact, while sovereign states, particularly developing countries, should strengthen governance, by enthroning GG, to enhance the SD-oriented initiatives of companies to advance societal goals, in terms of implementing their social responsibility, namely contributing to the wellbeing of their stakeholders, humanity and society at large.

Keywords: Global Compact, Business Sustainability; Sustainable Development (SD); Soft Law; Nigeria LNG Limited (NLNG); Bonny Kingdom (Ancient Grand Bonny Kingdom [Ancient Ibani Nation]); Partnerships; Principles; Voluntary; Corporate Social Responsibility (CSR); Social Investment; Social Licence to Operate; Good Governance (GG); World (Globe); and Planet Earth.
\end{abstract}

DOI: $10.7176 / \mathrm{JLPG} / 94-05$

Publication date: February $29^{\text {th }} 2020$

\section{Introduction}

This introduction will concentrate on the setting-up of the UN Global Compact, as a framework to advance corporate responsibility for the promotion of business sustainability and sustainable development (SD), in the process of ongoing efforts of the UN to achieve SD.

While tracing its roots to the works of Robert Prescott-Allen and the World Conservation Strategy (WCS), the preceding work to this study gives the classic definition of SD made by the World Commission on Environment and Development (WCED). This Commission in its celebrated report, entitled Our Common Future, defines SD as the development which meets the needs of the present without compromising the ability of future generations to meet their own needs. ${ }^{1}$ The previous study traces the ongoing progressive and increasingly advancing efforts of the UN on the twin relationship of the environment and development, towards SD, by outlining the UN Conferences so far in this regard. These are the Conference on the Human Environment (UNCHE), held at Stockholm, Sweden, in 1972 (following which the assembly of the world community took place in Nairobi, Kenya, from 10-18 May, 1982, and made the UN Nairobi Declaration of 1982); the Conference on Environment and Development (UNCED [also called the 'Rio Earth Summit'), held at Rio de Janeiro, Brazil, in 1992; the World Summit on SD (WSSD), held at Johannesburg, South Africa, in 2002; and the Conference on Sustainable

\footnotetext{
${ }^{1}$ The World Commission on Environment and Development (WCED), Our Common Future (Oxford University Press 1987 ), 8, 40 and 43.
} 
Development (UNCSD [Rio+20]), held again at Rio de Janeiro, in 2012. The initial study also indicates an acronym of these UN Conferences as 'SRJR', while describing the course of achieving SD pursuant to the SRJR Conferences and their ongoing outcomes, so far, as the 'SRJR Process'.

The UN Global Compact, which may be considered as a fall-out of ongoing economic globalisation premised on the efforts of the UN to achieve SD, is the world's largest corporate voluntary sustainability initiative launched about twenty years ago, in July 2000, by the Seventh UN Secretary-General, Kofi Annan (1 January, 1997 - 31 December, 2006). ${ }^{1}$ It is a global movement of sustainable companies, in the course of ongoing global efforts, being championed and superintended over by the UN, to foster and enhance the achievement of SD. The Global Compact so launched to unite business to advance corporate responsibility and thereby position business as force for good, such that business can take shared responsibility for achieving greater public good as well as a better, fairer, kinder, more just, sustainable and peaceful world on Planet Earth. The Compact is the world's foremost and largest corporate citizenship, responsibility and accountability framework, which is designed to exhibit and build social legitimacy of business and markets around the globe. ${ }^{2}$

The mission of the Global Compact is incorporated in its aim and vision. The aim of the Compact is to unite the private sector and thereby mobilise a global movement of sustainable companies and stakeholders to create a better world. ${ }^{3}$ The vison of the Compact is to encourage and support companies in two basic ways. These are namely to: (a) business responsibly, by aligning their strategies and operations with ten principles on human rights, labour, environment and anti-corruption; and (b) strategic actions to advance broader societal goals, such as the UN Development Goals, exemplified by the defunct UN Millennium Development Goals (UNMDGs) and the extant UN Sustainable Development Goals (UNSDGs), through collaboration and innovation towards SD. ${ }^{4}$

In the process, the Global Compact features as a platform and framework that inspires, guides and mobilises business towards business sustainability and SD. The Compact does so by providing a principle-based framework, best practices, resources and networking events that have revolutionised how companies do business responsibly and keep commitments to society. By so mobilising companies into action, the Global Compact fosters and enhances companies, whether small or big corporations, to enter into SD-oriented partnerships and collaboration, towards business sustainability and SD, wherever they operate around the globe. ${ }^{5}$

The Global Compact requires companies, to, at a minimum, embrace, support and streamline their operations in ways that conform to fundamental responsibilities, premised on ten principles, in the areas of human rights, labour, environment and anti-corruption. ${ }^{6}$ Applying and/or using the Global Compact as an inspirational guide, cases of good examples abound, concerning how companies enlisted to participate at the Compact are taking active voluntary steps to advance business sustainability and all-round SD around the world.

\section{A Glance at the Ten Principles of the Global Compact}

The ten principles of the Global Compact may be briefly considered under the following four headings, namely human rights, labour, the environment and anti-corruption. ${ }^{7}$ These principles are respectively derived from the Universal Declaration of Human Rights, $1948,{ }^{8}$ the declaration of the International Labour Organisation (ILO) on Fundamental Principles and Rights at Work, $1998,{ }^{9}$ the Rio Declaration on Environment and Development, 1992, ${ }^{10}$ and the United Nations Convention against Corruption, 2003/2005. ${ }^{11}$

Human Rights (Principles 1 and 2): Principle 1 of the UN Global Compact stipulates that businesses should support and respect the protection of internationally proclaimed human rights, ${ }^{12}$ while Principle 2 provides that businesses should ensure that they are not complicit in human rights abuses. ${ }^{13}$

${ }^{1}$ D. Thomas (Chief, Communications UN Global Compact Media), 'Executive Update: Statement by Lise Kingo, CEO \& Executive Director of the UN Global Compact, on the passing of former UN Secretary-General Kofi Annan', New York, United States of America, $<$ https://www.unglobalcompact.org/news/4399-08-18-2018> Accessed 7 February, 2020.

${ }^{2}$ Homepage of the UN Global Compact < https://www.unglobalcompact.org/> Accessed 7 February, 2020; UN Global Compact, 'Who are We: Business as a force for good' $<\mathrm{https}$ ://www.unglobalcompact.org/what-is-gc/mission> Accessed 7 February, 2020.

${ }^{3}$ The UN Global Compact, 'Who We Are'<https://www.unglobalcompact.org/what-is-gc/mission> Accessed 7 February, 2020.

${ }^{4}$ Ibid.

${ }^{5}$ Ibid; R. H. Cooper and J. V. Kohler (eds), Responsibility to Protect: The Global Moral Compact for the 21st Century (Palgrave Macmillan 2009); O. F. Williams, 'The UN Global Compact: The Challenge and the Promise' [2004] 14 (4) Business Ethics Quarterly, 755-774.

${ }^{6}$ Global Compact Network UK, 'The 10 Principles'<https://www.unglobalcompact.org.uk/the-ten-principles/> Accessed 7 February, 2020.

${ }^{7}$ UN Global Compact, 'The Power of Principles: The Ten Principles of the UN Global Compact' $<$ https://www.unglobalcompact.org/what-isgc/mission/principles $>$ Accessed 7 February, 2020.

${ }^{8}$ UN, 'Universal Declaration of Human Rights' $<$ https://www.un.org/en/universal-declaration-human-rights/> Accessed 7 February, 2020.

${ }^{9}$ ILO, 'ILO Declaration on Fundamental Principles and Rights at Work', 1998, <http://www.ilo.org/declaration/lang--en/index.htm> Accessed 7 February, 2020.

10 UN Audiovisual Library of International Law, 'Rio Declaration on Environment and Development' $<$ https://legal.un.org/avl/pdf/ha/dunche/rio_ph_e.pdf $>$ Accessed 7 February, 2020.

11 UN Office on Drugs and Crime (UNODC), 'United Nations Convention against Corruption' $<$ http://www.unodc.org/unodc/en/corruption/uncac.html > Accessed 7 February, 2020.

${ }^{12}$ UN, 'Universal Declaration of Human Rights' (n9).

${ }^{13}$ Ibid. 
Labour (Principles 3, 4, 5 and 6): Principle 3 of the Global Compact requires businesses to uphold the freedom of association and the effective recognition of the right to collective bargaining in the course of their operations and processes. Accordingly, Principle 4 of the Compact requires businesses to eliminate all forms of forced and compulsory labour, while Principle 5 of the Compact stipulates that companies should ensure effective abolition of child labour in their operational framework. Accordingly, Principle 6 of the Global Compact requires companies to eliminate discrimination in the context of their employment and occupational schemes. ${ }^{1}$

The Environment (Principles 7, 8 and 9): Principle 7 of the Global Compact requires businesses to support a precautionary approach to environmental challenges. Accordingly, Principle 8 of the Compact encourages businesses to undertake initiatives to promote greater environmental responsibility, while Principle 9 spurs businesses to encourage the development and diffusion of environmentally friendly technologies. ${ }^{2}$

Anti-Corruption (Principle 10): Principle 10 of the Global Compact motivates and requires businesses to work against all forms of corruption, including extortion and bribery, in the course of their operations and processes. $^{3}$

The foregoing brief analysis demonstrates that corporate sustainability starts with a company's SD-oriented value system and consequently its principled approach to doing business. ${ }^{4}$ Consequently, companies enlisted into the framework of the Compact are required and encouraged to uphold and implement these ten principles wherever they operate, so as to enable them add value to the society, namely to make society a better place, through bettering the lives and wellbeing of their stakeholders (stakeholder-populace) and society at large. By incorporating these ten principles into their strategies, policies and procedures and establishing a culture of integrity, companies are certainly not only upholding their basic responsibilities to people, society and the Planet Earth, but also setting the stage for their long-term success, namely sustainability of their businesses or business organisations. Resoundingly, by internalising these principles and other initiatives, values and strategies of the Global Compact into their policies, operational procedures and processes, companies enlisted into the framework of the Compact are establishing a culture of integrity and thereby contributing to business sustainability and SD, towards greater human wellbeing and a better global society. ${ }^{5}$

Given that these principles of the Global Compact are aimed at helping to improve and advance corporate responsibility within and around the globe, some examples of active steps being taken by companies to improve corporate responsibility and the advancement and sustainability of business operations around the globe may be considered. ${ }^{6}$

\section{The Global Compact: Examples of Good Performances of Companies to Advance Corporate Social Responsibility (CSR) towards Business Sustainability and SD}

Regardless of some identified challenges associated with the Global Compact, ${ }^{7}$ cases of good examples abound concerning how companies participating at the Global Compact are taking active voluntary steps to advance business sustainability and SD, through responsibility, accountability and transparency, in the course of their operations around the world. ${ }^{8}$

There are numerous good examples of corporate social responsibility (CSR) towards business sustainability and SD, which include those of Coca-Cola, which is fighting corruption in Myanmar, in Southeast Asia, by adopting a zero-tolerance policy towards corruption in its operations and for its value chain that includes its bottlers. ${ }^{9}$ There is also the case of Uganda's Entebbe Handling Services (ENHAS) promoting good health, by offering passenger and cargo handling services in Entebbe (in Uganda), Kinshasa (in Democratic Republic of Congo) and Juba (in South Sudan). ENHAS focuses on good health for its employees, understanding that good health means good business. ${ }^{10}$

${ }^{1}$ ILO, 'ILO Declaration on Fundamental Principles and Rights at Work', 1998 (n10).

${ }^{2}$ UN Global Compact, 'The Power of Principles: The Ten Principles of the UN Global Compact' (n9).

${ }^{3}$ Ibid.

${ }^{4}$ Ibid.

${ }^{5}$ Ibid; homepage of the Earth Charter Initiative <http://earthcharter.org/> Accessed 7 February, 2020.

6 UN Global Compact, 'Take Action: Join the UN Global Compact Academy' Join the UN Global Compact Academy, $<$ https://www.unglobalcompact.org/take-action> Accessed 7 February, 2020

${ }^{7}$ A. Rasche and G. Kell (ed), The United Nations Global Compact: Achievements, Trends and Challenges (Cambridge University Press 2010); UN, United Nations Global Compact Inspirational Guide: Human Rights, Labour, Environment, Anti-corruption, Partnerships for Development (UN 2008)

${ }^{8}$ UN Global Compact, Business Solutions for Sustainable Development: Case Examples Global Compact LEAD from Global Compact LEAD Companies (UN Global Compact Lead/Best Practice Institute) <https://www.unglobalcompact.org/docs/issues_doc/lead/SDCaseStudies.pdf $>$ Accessed 7 February, 2020; C. Fussler et al (eds), Raising the Bar: Creating Value with the UN Global Compact (Routledge 2017); J. T. Lawrence and P. W. Beamish (eds), Globally Responsible Leadership: Managing According to the UN Global Compact (SAGE Publications 2013); O. F. Williams (ed), Sustainable Development: The UN Millennium Development Goals, the UN Global Compact, and the Common Good (University of Notre Dame Press 2014).

${ }^{99}$ UN Global Compact, 'Coca-Cola's fight against corruption in Myanmar' < https://www.unglobalcompact.org/take-action/action/caseexample/113 $>$ Accessed 7 February, 2020; Homepage of Coca-Cola, $<$ https://www.coca-cola.com/ $>$ Accessed 7 February, 2020.

${ }^{10}$ UN Global Compact, 'At ENHAS good health means good business' <https:/www.unglobalcompact.org/take-action/action/case- 


\subsection{First Good CSR Example: IKEA's Commitment to Children}

Among numerous good cases of CSR in the course of the day-to-day operations of businesses around the globe, our first example is the case of IKEA, a European multinational and global group of home furnishing companies, having their headquarters in Sweden. ${ }^{1}$ It is making commitment to children, by preventing child labour in its supply chain. ${ }^{2}$ IKEA does so by developing long-term partnership programmes with child rights organisations to prevent and eliminate child labour in rural communities. These programmes include creating awareness and mobilising its rural host communities to ensure children's enrolment in schools, and how the children are able to properly attend school towards successful completion of their early educational career.

Another important component of IKEA's programme, which is designed to help its rural host communities and stakeholders, is its provision of credit-facilities and other income generating opportunities for women. This programme is designed to boost the economic, socio-cultural and legal status of women in their communities. IKEA reduces financial burden on rural women so as to encourage them to support their children's education, rather than send the children to work and earn a living to support their parent's welfare. The programme thus improves the general wellbeing of women and their families in IKEA's rural host communities. ${ }^{3}$

\subsection{Second Good Example of CSR: Safaricom's App Keeping Kenyan Children Safe}

Our second good CSR example is Safaricom, a leading communications company in Kenya, having strong and wide information and communication technology [ICT] coverage in the country. ${ }^{4}$ Safaricom developed a free ICT application called 'Guardian Application', to help keep youngsters safe from dangers of contemporary ICT facilities, such as cyberbullying and other electronic media related forms of abuses and risks affecting youngsters. ${ }^{5}$

It is of public knowledge that youngsters are exposed to online violence and other forms of abuses and risks, arising from the use of contemporary ICT devices such as smartphones, tablets and computers, which expose youngsters to the world at large. These devices also expose youngsters to unsuspecting but dangerous adults, who often abuse youngsters that they contact online. Consequently, with the help of 'Guardian Application', parents and guardians can choose individuals and groups in the outside world that can communicate with their children and wards, and thereby protect such youngsters, who may be unduly influenced and maltreated, from unwanted communications such as short message services (SMS) sent by strange adults. This Application also helps parents and guardians to restrict or block internet functions, and thereby prevent children from downloading or installing certain online applications that may endanger them. Besides, Guardian Application is so simple to use so that parents and guardians do not need technical expertise or knowledge to use it. Safaricom also encourages parents and guardians to educate their children on responsible use of modern communication devices, such as smartphones and tablets, particularly in terms of accessing or engaging in online communication features that may harm youngsters in our increasingly advancing era of ICT. ${ }^{6}$

\subsection{Third Good CSR Example: Anglo-American's Fight against HIV/AIDS in Southern Africa}

Our third good example of CSR is about Anglo-American, which is one of the world's largest mining companies, having its group headquarters in London, United Kingdom. ${ }^{7}$ Anglo-American is widely recognised for its approach to SD, such that it had the highest score of the assessment of mining companies in the 2012 Dow Jones Sustainability Index (DJSI). This recognition of Anglo-American was in part due to its longstanding efforts in terms of addressing the maladies of HIV/AIDS and tuberculosis (TB) within its workforce in Southern Africa. DJSI is a strategic world-wide partnership benchmarked sustainability framework that evaluates sustainability performance of thousands of public companies based on their distinct sectors and geographical areas of operations. $^{8}$

Anglo-American's HIV/AIDS workplace programme involves a five-pillar approach, namely (i) focusing on voluntary counselling and testing; (ii) spreading awareness, education and prevention; (iii) ensuring care, support

example/118 $>$ Accessed 7 February, 2020

${ }^{1}$ IKEA, 'Inter IKEA Group' <https://inter.ikea.com/en/contact/contact-details/>; IKEA, 'IKEA Family' <https://www.ikea.com/jp/ja/> both Accessed 7 February, 2020

${ }^{2}$ UN Global Compact, 'UN Global Compact: IKEA's Commitment to Children' $<$ https://www.unglobalcompact.org/take-action/action/caseexample/101> Accessed 7 February, 2020.

${ }^{3}$ Ibid.

${ }^{4}$ Homepage of Safaricom, $<$ https://www.safaricom.co.ke/> Accessed 7 February, 2020.

${ }^{5}$ UN Global Compact, 'Safaricom's App Keeping Kenyan Children Safe' $<$ https://www.unglobalcompact.org/take-action/action/caseexample/102> Accessed 7 February, 2020; Apps and Software/Technology, 'Safaricom Guardian App - Giving You Parental Control Over Your Child's Smartphone' <https://innov8tiv.com/safaricom-guardian-app-giving-parental-control-childs-smartphone/amp/> Accessed 7 February, 2020

${ }^{6}$ Ibid.

${ }^{7}$ Homepage of Anglo-American, <https://www.angloamerican.com/>Accessed 7 February, 2020.

8 UN Global Compact, 'Anglo-American's Fight against HIV/AIDS in Southern Africa' <https:/www.unglobalcompact.org/takeaction/action/case-example/104> Accessed 7 February, 2020. 
and treatment; (iv) creating partnerships; and (v) promoting a commitment to Anglo American's values. ${ }^{1}$

In the context of this approach, Anglo-America guarantees confidentiality of information on members of its workforce infected by HIV/AIDS and implements its non-discrimination policy about sustainability of employment of such infected workers. Accordingly, Anglo-American has since 2002 been giving free antiretroviral treatment to all its employees infected by HIV/AIDS, as well as intervening in such cases of individuals within its supply chain, and has thereby considerably reduced the effects of HIV/AIDS in its production cycle. $^{2}$

\subsection{Fourth Good CSR Example: Barrick Gold's Work to Ensure Access to Clean Water}

Our fourth good CSR example is Barrick Gold, a Canadian-based mining company, which encourages local communities to participate in the company's water monitoring activities at its Pascua-Luma mine in Chile. ${ }^{3}$

In 2013, Barrick Gold trained community representatives of Pascua-Luma on how to undertake water sampling. Thereafter, the company invited the community representatives to test water quality at several different monitoring points along the El Carmen River. The representatives subsequently delivered the tests they conducted to an independent and accredited laboratory of their choice in Santiago, the capital of Chile. To improve the authenticity and transparency of the process, public monitors collected the results of the evaluation and clarified same, in conformity with acceptable technical standards of water quality. ${ }^{4}$

Barrick Gold also conducted similar water testing initiatives at its Lagunas Norte gold mine in Peru and its Veladero gold mine in Argentina. This activity of Barrick Gold supports the achievement of a basic human right and delivery of its associated Sustainable Development Goal (SDG), namely 'access to water and sanitation for all' ${ }^{5}$

\subsection{Fifth Good Example of CSR: Microsoft's Efforts to Preserve the Cherokee Language}

Our fifth good example of CSR is the exemplary effort of Microsoft (a US multinational technology firm having its headquarters in Redmond, Washington DC), to preserve the Cherokee language, by developing the Local Language Program (LLP), which is a global initiative dedicated to providing individuals with access to desktop computer software in their own native language. ${ }^{6}$ The Cherokee Nation, also known as the Cherokee Nation of Oklahoma, is the largest tribal nation of the three Cherokee federally recognised tribes in the United States of America (USA)?

In 2012, Microsoft developed a Language Interface Pack (LIP) for Windows in the Cherokee language, which translates and displays most of the commonly used user interface of Windows into Cherokee. A dedicated team of Microsoft worked closely with members of Cherokee Nation, who referenced cultural texts in order to create new words as may be required for translation. The Microsoft team also worked with a Cherokee typist, to help create a phonetic keyboard and new font specific to Cherokee language. ${ }^{8}$

Microsoft also partnered with the Cherokee Nation to develop technology modules and other IT skills classes for Cherokee youngsters that are solely taught in Cherokee language. The Microsoft Cherokee young people's language training sessions are aimed at preserving the Cherokee language in the interest of their future generations. ${ }^{9}$

\subsection{Sixth Good Example of CSR-in-action: Microsoft's Efforts to Preserve the Cherokee Language}

Our sixth example of CSR-in-action is about the exemplary efforts of Sakhalin Energy Investment Company Limited (SEICL), ${ }^{10}$ a Russian company operating an integrated oil and gas project in Sakhalin Island, in the Far East of Russia, along North of the Pacific Ocean), concerning preservation of the Sakhalin people's indigenous culture. $^{11}$

In consultation with Sakhalin's four main indigenous groups, namely Nivkhi, Uilta (Orok), Evenki and Nanai, in 2012, SEICL developed the Sakhalin Indigenous Minorities Development Plan (SIMDP), which seeks to

\footnotetext{
${ }^{1}$ Ibid.

${ }^{2}$ Ibid.

${ }^{3}$ UN Global Compact, 'Barrick Gold's Work to Ensure Access to Clean Water' < https://www.unglobalcompact.org/take-action/action/caseexample/105> Accessed 7 February, 2020.

${ }^{4}$ Ibid

5 Ibid; Goal 6, UN Sustainable Development Goals, captioned 'Goal 6: Ensure access to water and sanitation for all' $<$ https://www.un.org/sustainabledevelopment/water-and-sanitation/> Accessed 7 February, 2020.

${ }^{6}$ UN Global Compact, 'Microsoft's efforts to preserve the Cherokee Language' $<\mathrm{https}$ ://www.unglobalcompact.org/take-action/action/caseexample/106> Accessed 7 February, 2020.

${ }^{7}$ Homepage of the Cherokee Nation of Oklahoma, USA, <https://www.cherokee.org/> Accessed 7 February, 2020.

${ }^{8}$ UN Global Compact, 'Microsoft's efforts to preserve the Cherokee Language' (n38).

${ }^{9}$ Ibid.

${ }^{10}$ Homepage of Sakhalin Energy, <http://www.sakhalinenergy.ru/en/> Accessed 7 February, 2020.

${ }^{11}$ UN Global Compact, 'Sakhalin Energy and the preservation of Indigenous Culture' <https://www.unglobalcompact.org/library/1651> Accessed 7 February, 2020.
} 
mitigate negative impacts of SEICL's project in the area and to share benefits of the project with the people of the area. The designing and implementation of the SIMDP, including a grievance procedure associated therewith, were done in consultation with the Sakhalin indigenous people. In the process, a special committee of representatives of the indigenous people, made decisions on how SIMDP funds are utilised. ${ }^{1}$

SEICL, otherwise simply called Sakhalin Energy, pays special attention to initiating projects to preserve indigenous languages and culture. Some of these projects are (i) publication of the first ABC book of the Uilta language; (ii) publication of a series of books, which include the Tales of the Northern Country for the Children of Sakhalin in Nivkh and Russian and a Cultural Heritage of the Peoples of the Russian Far East series; (iii) production of Quiet Songs of Ancestors with Nivkh folk songs; (iv) development and publication of a number of language books and dictionaries in native languages, which include Uilta, Nivkh and Russian languages; and (v) a separate joint project of SEICL and the Russian Office of the UN High Commissioner for Human Rights, to publish the Universal Declaration of Human Rights and the UN Declaration on the Rights of Indigenous Peoples in Sakhalin indigenous languages. ${ }^{2}$

The foregoing exemplary efforts demonstrate SEICL's business sustainability and SD efforts within and among the indigenous peoples of Sakhalin in Russia.

\subsection{Seventh Good Example of CSR: Banco do Brasil Climate Change Adaptation Efforts to Support Farmers}

Our Seventh good example of CSR is the Climate Change adaptation case of Banco do Brasil (Brazil's first financial institution and currently the largest financial institution in Latin America) in the form of supporting farmers, who are considered as potentially valuable change agents concerning impacts of climate change. ${ }^{3}$ The efforts of Banco do Brasil in this regard are crucial and necessary, considering that about 29 percent of Brazilian land is used for agricultural-livestock production activities, while about 82 percent of Brazilian water is consumed by the rural sector. Brazilian agricultural sector and water resources are subject to adverse impacts of climate change in the country. ${ }^{4}$

In 2010, Banco do Brasil entered into partnership with Brazil's National Water Agency (ANA) and the World Wide Fund for Nature (WWF), to develop the Agua Brasil programme, which is designed, among other related objectives, to promote societal awareness and attitudinal change towards environmentally sound water resource management and conservation. ${ }^{5}$

As pilot projects of Agua Brasil, its partners have 14 important watersheds, located in the Cerrado/Pantanal, Atlantic Forest, Amazonia, Caatinga and Pampa biomes. These pilot projects will involve the creation of local water management plans, including water foot-printing and training of basin committees and other stakeholders on improved watershed management. The aim of these projects is to improve the quality of water and to increase water supply in the catchment basins of Agua Brasil water project. ${ }^{6}$

Agua Brasil, which is designed to ensure effective management of the impacts of climate change, would lessen the impacts on the surrounding ecosystem, and thereby boost resilience of affected individuals, families and communities and contribute to climate change mitigation schemes. As such, for example, Agua Brasil family members engaged in agriculture are embarking on new practices to improve water supply, so as to alleviate the adverse impacts of climate change on sources of water supply to family land, crops and livestock. Also, through Agua Brasil, farmers are to have access to an expanded range of financial products and services, including credit facilities, as incentives to assist and encourage them to implement climate friendly and sustainable farming techniques, so as to improve their livelihoods. The emphasis of Agua Brasil on dissemination of best practices, built into the framework of supportive financial incentives, are designed to promote and ensure climate friendly and climate-resilient activities among Brazilian farming communities. ${ }^{7}$

\subsection{Eighth Good CSR Example: LG Electronics and its Supply Chain Management Aimed at Addressing the Problem of Armed Groups Smuggling Mineral Resources Out of the Republic.in the Democratic Republic of Congo}

Our eighth good CSR example is about LG Electronics (LG) and supply chain management in Central Africa's Democratic Republic of Congo (DRC). LG is a multinational electronics company, the flagship of LG Group, headquartered in Seoul, South Korea, which manufactures electronic and telecom products, operating in well over

\footnotetext{
${ }^{1}$ Ibid.

${ }^{2}$ Ibid.

${ }^{3}$ UN Global Compact, 'Climate Change Adaptation by Banco do Brasil' <https://www.unglobalcompact.org/take-action/action/caseexample/110> Accessed 7 February, 2020 .

${ }^{4}$ Ibid.

${ }^{5}$ Ibid.

${ }^{6}$ Ibid.

${ }^{7}$ Ibid.
} 
80 countries. $^{1}$

DCR, which is endowed with vast mineral wealth, has for many years been confronted with the problem of her armed groups smuggling mineral resources out of the Republic. In conformity with the requirements of the US Securities and Exchange Commission (SEC), ${ }^{2}$ LG addressed this problem of DRC by devising a reporting system that ascertains the origin of 'conflict minerals', by virtue of the flow of funds associated with such mineral resources, through its supply chain. ${ }^{3}$

\subsection{Ninth Exemplary CSR-in-action: Social Investment of Nestlé Lanka on Dairy Farmers in Sri Lanka}

Our ninth example of exemplary CSR-in-action is about the social investment of Nestlé Lanka on dairy farmers in Sri Lanka. Nestlé, having its headquarters in Vevey, Switzerland, is a leading global nutrition, health and wellness company, which operates in about 194 countries. ${ }^{4}$ The subsidiary of Nestlé in Sri Lanka, Nestlé Lanka, has been operating for over 100 years and is one of the top food and beverage companies in Sri Lanka. Nestlé Lanka provides direct employment to almost 1,200 people and thus impacts on the livelihoods of over 23,000 suppliers, farmers and their families in the country.

Due to civil war, which ravaged the country from 1983 - 2009, the dairy industry in Sri Lanka's Northern and Eastern provinces is not flourishing optimally. These provinces produce only about 15 per cent of Sri Lanka's milk, despite accounting for almost 34 per cent of the country's cattle. Many farmers in these provinces fled during the war and left their livestock behind. When they returned, they found it difficult to locate their livestock, as many of them had roamed away. Worse still, the farmers did not have title or fixed title over their land. As such, they could not secure their land or even obtain land for grazing. Nestlé had to rescue the farmers by educating them on animal husbandry, so as to take good care for their animals and to improve the quality and quantity of milk they produce. Nestlé rescued the farmers by giving them incentives, such as interest-free loans and revolving credit facilities, on affordable terms, such as commitment to simple and flexible guarantees. The farmers are therefore able to secure interest-free credits with which they purchase cattle, cattle sheds and pasture plots. The not cumbersome form of guarantees granted by Nestlé Lanka to the farmers boosted sustainability of local dairy farmers in Sri Lanka, business sustainability for Nestlé Lanka and partnership of both parties for public good towards the advancement and SD of Sri Lankan dairy farming business. ${ }^{5}$

\subsection{Tenth Good Example of CSR-in-action: Pacific Rubiales Energy's Efforts to Ensure Safety of its Workforce}

Our tenth good CSR example is about the work of Pacific Rubiales Energy (PRE: the largest independent oil and gas exploration and production company in Colombia, whose biggest oil production asset is located in the municipality of Puerto Gaitán) to ensure safety of its workforce. ${ }^{6}$

Puerto Gaitán is a geopolitically risky area for oil and gas operations, due to disputes and violent civil unrest between guerrillas and paramilitary groups over land being used as a base for drug trafficking in the area. During a violent civil unrest which took place in the area, on 19 July, 2011, PRE experienced a blockade that made it to stop operations. In order to ensure the safety of its workers as a result of the blockade, government promoted a form of collaborative dialogue and negotiation took place, which PRE committed itself to ensure it succeeded, by sponsoring same as a guarantor. This committed approach of PRE is to demonstrate its responsibility, accountability of its supply chain, including the control procedures of this chain, as well as acting in compliance to its workforce union-related rights and responsibilities. Eventually, a Social Agreement, which established a new Corporate Social Responsibility Policy (CSRP) for PRE that was aimed at addressing all the concerns of the community, was signed in September 2011. The agreement consisted of 91 commitments (PRE is responsible for 65 of them and the community for 26) including actions and guidelines on social, environmental, indigenous, cultural, commercial and labour matters. These commitments of CSRP for PRE are being collaboratively executed by all levels of government, the local community, and PRE, and thus resulting in a consensus-building, win-win situation for all the parties. ${ }^{7}$

Ultimately, such a committed approach of PRE, which focused on industrial peace, harmony and development, enabled the company to secure and strengthen its long-term social licence to operate, and thereby minimised the negative effects of its operations, towards business sustainability, sustained health, safety and environmental protection measures for PRE's workforce and sustainable community development (SCD) in the Puerto Gaitán

\footnotetext{
${ }^{1}$ Homepage of LG, <http://www.lgcorp.com/about/companies > Accessed 7 February, 2020.

${ }^{2}$ Homepage of the US SEC, <https://www.sec.gov/> Accessed 7 February, 2020.

UN Global Compact, 'LG Electronics and supply chain management in the Democratic Republic of Congo' $<$ https://www.unglobalcompact.org/take-action/action/case-example/114

${ }^{4}$ Homepage of Nestle, <https://www.nestle.com/> Accessed 7 February, 2020.

${ }^{5}$ Ibid.

${ }^{6}$ UN Global Compact, 'Pacific Rubiales Energy's work to ensure worker's safety' $<$ https://www.unglobalcompact.org/take-action/action/caseexample/116> Accessed 7 February, 2020

${ }^{7}$ Ibid; R. Sidaway, Resolving Environmental Disputes from Conflicts to Consensus (Earthscan 2013).
} 
communal area of Columbia. ${ }^{1}$

\subsection{Eleventh Good Example of CSR: SAB Miller's Collective Action in India}

The next (eleventh) good example of CSR is the collective action of a brewing and beverage company, SAB Miller, ${ }^{2}$ in India.

SAB Miller started several collaborative programmes to ameliorate scarce ground water supply in India. As a result, through a local collaborative process, the company sponsored the establishment of a grid of 100 irrigationenhanced observation farms involved in crop demonstration trials, in order to monitor ground water conditions, such as usage patterns, in the affected areas. These collaborative-partnership crop demonstration trials, which focused on integrated nutrient management and enhancement of irrigation efficiency, are encouraging in terms of cost-benefit ratio of additional incomes to additional investments of famers. So far, more than 200 farmers are participating in these irrigation-enhanced observation farms. The impact of these collaborative partnership programmes on local deep groundwater levels was ascertained and in July 2010 recorded with a net rise of approximately 56 feet (17.0688 meters) around the three groundwater recharge structures that were constructed on government land in the ridge area of the programmes. ${ }^{3}$

\subsection{Twelfth Good CSR Example: Mark Pharmaceutical Limited Water Efficiency Measures in its Areas of Operations}

Our twelfth good CSR example is that of Mark Pharmaceutical Limited (MPL: a leading global brand in pharmaceutical products in Nigeria, which imports and markets pharmaceuticals products in the country $)^{4}$ that embarks on water efficiency measures in its areas of operations in the country. It is on record that MPL employs a variety of technologies and techniques aimed at reducing its water usage and improving operational performance. ${ }^{5}$ It employs closed-loop cooling systems within over half of its facilities to reduce its use of freshwater, by approximately 3.3 billion gallons a year. It re-uses reverse osmosis (RO) reject water for nonpotable and non-process applications such as cooling-tower feed water, fire water and irrigation, and this system of re-use saves an estimated 50 million gallons of freshwater yearly. MPL has committed approximately \$67 million from a $\$ 100$ million capital reserve fund to improve infrastructure, so as to help achieve its water commitments within its operating facilities. ${ }^{6}$

\subsection{Thirteenth Good Example of CSR-in-action: NLNG's Approach to CSR in its Host Communities}

Our thirtieth and last good example of CSR-in-action is about Nigeria LNG Limited (NLNG). NLNG, incorporated on May 17, 1989, to harness Nigeria's vast natural gas resources, to produce Liquefied Natural Gas (LNG) and Natural Gas Liquids (NGLs) for export, promotes itself as a world-class LNG company, which is helping to build a better Nigeria. ${ }^{7}$ As the arrowhead of Nigeria's efforts to eliminate gas flaring, NLNG's operations have helped reduce Nigeria's flaring profile from 65 per cent to below 25 per cent. NLNG supplies about 40 per cent of the annual domestic Liquefied Petroleum Gas (LPG: cooking gas) for domestic consumption in Nigeria. ${ }^{8}$

NLNG, which joined the UN Global Compact on December 26, 2015, ${ }^{9}$ (by virtue of its letter to the UN

\footnotetext{
${ }^{1}$ J. Morrison, The Social Licence: How to Keep Your Organization Legitimate (Palgrave Macmillan 2014); L. Black, The Social Licence to Operate: Your Management Framework for Complex Times (Routledge 2017); J. Morrison, International Business Challenges in a Changing World (Springer Nature 2019); K. K. Aaron, Corporate Social Responsibility Performance in the Niger Delta: Beyond Two Constitutive Orthodoxies' [2011] 21 (6) Development in Practice, 779-789; E. Wilson, 'What is Social Licence to Operate? Local Perceptions of Oil and Gas Projects in Russia's Komi Republic and Sakhalin Island'[2016] The Extractive Industries and Society, 3 (1) 73-81; K. Elendu, 'Social Licence to Operate: A Solution to Community Crises with Oil Companies'<https://medium.com/@kingsonelendu/social-licence-to-operate-asolution-for-community-crises-with-oil-companies-b9b3b669e8ab>; KPMG, 'Opportunities to Strengthen Social Licence for Oil and Gas Companies'<https://home.kpmg/au/en/home/insights/2019/06/social-licence-for-oil-and-gas.html>; J. Bairstow, Oil and Gas Industry's 'Social Licence to Operate under Serious Threat' <https://www.energylivenews.com/2020/01/17/oil-and-gas-industrys-social-licence-to-operateunder-serious-threat/> all Accessed 7 February, 2020; L. Barrera-Hernandez et al (eds), Sharing the Costs and Benefits of Energy and Resources Activity: Legal Change and Impact on Communities (Oxford University Press 2016).

${ }^{2}$ UN Global Compact, 'SAB Miller's Collective Action in India' <https://www.unglobalcompact.org/take-action/action/case-example/112> Accessed 7 February, 2020.

${ }^{3}$ Ibid; L. Stott (ed), Shaping Sustainable Change: The Role of Partnership Brokering in Optimising Collaborative Action (Routledge 2019).

${ }^{4}$ Homepage of Mark Pharmaceutical Limited, <https://markpharmltd.com/index.html $>$ Accessed 7 February, 2020.

${ }^{5}$ UN Global Compact, 'Merck's Water Efficiency Measures'<https://www.unglobalcompact.org/take-action/action/case-example/111> Accessed 7 February, 2020

${ }^{6}$ Ibid.

' Homepage of NLNG, 'A Global Company ...helping to build a better Nigeria' < http://nlng.com/nignlng/home.aspx > Accessed 7 February, 2020.

${ }^{8}$ Ibid; NLNG, 'Profile'<http://nlng.com/Our-Company/Pages/Profile.aspx > Accessed 7 February, 2020.

9 UN Global Compact: Nigeria Liquified Natural Gas: Company Information' <https://www.unglobalcompact.org/what-isgc/participants/73681-Nigeria-Liquefied-Natural-Gas $>$ Accessed 7 February, 2020; NLNG Letter of Commitment to the UN Secretary-General, Ban Ki-Moon, signed by NLNG's Managing Director and CEO, Babs Omotowa, with reference no. NLNG/MD/GRC/2015/122, dated 7 December, $\quad 2015, \quad<\mathrm{https} / / / \mathrm{s} 3$-us-west-2.amazonaws.com/ungcproduction/commitment_letters/73681/original/UNGC_Business_Commitment_Letter_Signed.pdf?1450255519> Accessed 7 February, 2020.
} 
Secretary-General), is owned by four shareholders, namely the Federal Government of Nigeria (represented by Nigerian National Petroleum Corporation [49 percent]); Shell Nigeria (The Shell Petroleum Development Company of Nigeria Limited [SPDC] 25.6 percent); Total Gaz Electricite Holdings France (15 percent) and Eni (10.4 percent). The establishment of NLNG is backed by the NLNG Act. ${ }^{1}$

Based on the percentage of its shareholding in NLNG, among other roles in incentives within NLNG, Shell Nigeria produces the Managing Director and Chief Executive Officer of NLNG. Accordingly, NLNG is considered part of the Shell companies in Nigeria and Shell Nigeria's parent company (the Royal Dutch Shell Plc (Shell Global), ${ }^{2}$ which joined the UN Global Compact since 26 July, $2000 .^{3}$

The business principles and values of NLNG are aimed at contributing to SD, in order to be a trusted partner in its relations with all its stakeholders, which include its host communities. Thus, in terms of community relations, NLNG operates an open-door policy, whereby its officers regularly meet (formally and informally) with representatives of its host communities, to foster and maintain good relationships as well as to enhance mutual advancement. $^{4}$

Consequently, NLNG's approach to CSR in its host communities is anchored on sustainability, stakeholding and partnership. In the process, while championing best practices in community relations, NLNG introduced a new strategy called Community Driven Development Strategy (CDDS), by which NLNG and its Bonny Joint Industry Companies (JIC) partners moved from the prevailing practice of company driven community development to community driven development and sustainability. In the course of this strategy, NLNG supports and superintends over community development plans, policies and programmes, including projects (PPPs) in its host communities to generate their developmental needs, while NLNG and its JIC partners contribute funds to cater for their social investments in the communities. NLNG highlights that pilot implementation of its CDDS is being carried out in its primary host Ancient Grand Bonny Kingdom (simply called Bonny Kingdom), where the Bonny Utility Company (BUC) manages the provision of such social investment projects of the Bonny JICs, as electricity and water supply services in Bonny Island. These social investment projects in Bonny Island are funded by the Bonny JICs, comprising NLNG, Shell Nigeria (SPDC) and Exxon Mobil, with a contribution ratio of 50:30:20, respectively. ${ }^{5}$

NLNG, through its Bonny JICs partners, is currently engaged in the proposed Bonny Kingdom Development Foundation (BKDF). An annual sum of over Four Billion Naira is earmarked by the Bonny JICs, led by NLNG, to fund the proposed BKDF, so as to cater for the JICs social investments in Bonny Kingdom (which is NLNG's primary host Kingdom), towards the wellbeing of the people and communities of the Kingdom. ${ }^{6}$ The communities of the Kingdom include those that have direct legally binding relationships with NLNG, namely the NLNG's involuntarily resettled Finima Community, its Gas Transmission System (GTS)/Pipeline Communities and Bonny Island (Grand Bonny [the Island Capital City of the Kingdom and Bonny Local Government Area). NLNG's Bonny GTS Communities are Kuruama, Ayama (Peterside), Orupiri (the first community established by the Founding Ancestors of Ancient Grand Bonny Kingdom [Ancient Ibani Nation]), Ayaminima and Akiama, including the NLNG Abalamabie water-well community. The proposed BKDF is specifically meant to fund such existing Bonny JICs' public utilities within and along Bonny Island as the Bonny Utilities Company (BUC, which is catering for the generation and supply of electricity and water in Bonny Island and Finima Community [New Finima]), the Bonny Vocational Centre (BVC), Ibanise Health Initiative and the Bonny Integrated Recruitment Centre (BIRC). ${ }^{7}$

Based on the foregoing and NLNG's other social investments in its primary host, Bonny Kingdom, which include its environmental protection, management and conservation PPPs such as its Finima Nature Park ${ }^{8}$ environmental conservation effort of NLNG within Finima Community and Bonny Island, as well as its numerous social responsibilities-in-action towards helping to build a better Nigeria, NLNG is clearly a leader of social responsibility among the multinational oil and gas companies (MNOCs) operating in Bonny Kingdom and Nigeria

\footnotetext{
${ }^{1}$ Nigeria LNG (Fiscal Incentives, Guarantees and Assurances) Act, Cap N87 Laws of the Federation of Nigeria (LFN) 2004.

2 Homepage of the Royal Dutch Shell <https://www.shell.com/> Accessed 7 February, 2020; Shell Global, 'Who We Are' $<$ https://www.shell.com/about-us/who-we-are.html $>$ Accessed 7 February, 2020; Shell in Nigeria, Shell in Nigeria: Our business activities in Nigeria $<$ https://www.shell.com.ng/about-us/who-we-are.html $>$ Accessed 7 February, 2020.

${ }^{3}$ UN Global Compact, 'Royal Dutch Shell Plc: Company Information' <https://www.unglobalcompact.org/what-is-gc/participants/8082Royal-Dutch-Shell-plc> Accessed 7 February, 2020.

${ }^{4}$ NLNG, Our Company: Business Principles'<http://nlng.com/Our-Company/Pages/Business-Principles.aspx\#> Accessed 7 February, 2020; NLNG, NLNG: 'Our CSR: Approach to CSR'<http://nlng.com/Our-CSR/Pages/Approach-to-CSR.aspx > Accessed 7 February, 2020.

${ }^{5}$ NLNG, NLNG: 'Our CSR: Approach to CSR' (n70); NLNG, 'NLNG: Our CSR: Joint Industry Companies' <http://nlng.com/OurCSR/Pages/Joint-Industry-Companies-projects.aspx $>$ Accessed 7 February, 2020; NLNG, 'Community Projects and Programmes' $<$ http://nlng.com/Our-CSR/Pages/Community-Projects-and-Programmes.aspx $>$ Accessed 7 February, 2020.

${ }^{6}$ NLNG, NLNG: Our Company: Host Communities'<http://nlng.com/Our-Company/Pages/Our-Community.aspx $>$ Accessed 7 February, 2020. ${ }^{7}$ Memorandum of Understanding (MoU) Between Bonny Kingdom (Represented by the Amanyanabo of Bonny Kingdom, King Edward Asimini William Dappa Pepple III, JP, CON, Perekule XI) AND The Joint Industry Companies (Comprising Nigeria LNG Limited [NLNG] and The Shell Petroleum Development Company of Nigeria Limited [SPDC] for Sustainable Development of Bonny Kingdom.

${ }^{8}$ NLNG, 'NLNG: Our Environment: Conservation'<http://nlng.com/Our-Environment/Pages/Conservation.aspx > Accessed 7 February, 2020.
} 
at large. ${ }^{1}$ NLNG is engaged in business sociability associated with social responsibility towards sustainable community development (SCD) and empowerment of its primary host Finima and Bonny Island Communities, as well as its Abalamabie water-well Community and its about 110 GTS Communities of Rivers State, Nigeria. ${ }^{2}$

However, a major problem and drawback of NLNG's community relations strategy in Bonny Kingdom is that its management often unduly takes side in community controversies, which is associated with its operations in the Kingdom. Many are of the opinion that this problem of NLNG in Bonny Kingdom is particularly associated with Shell Nigeria (SPDC), which commenced such a dishonourable community relations strategy in the oil-rich communities of the Niger Delta region. There is therefore a need for NLNG to reappraise such a community relations strategy, by clearly operating as a world-class LNG company, without undermining any legitimate interest of its host communities and the people of these communities, especially less privileged and socially weak people and groups in these communities. NLNG should necessarily do so, in order not to be publicly declared complicit in human and environmental rights abuses in its host communities as Shell Nigeria was, even while it (Shell Nigeria) was concentrating more on its Agama Lizard form of self-praise about its social investments in the Delta region. ${ }^{3}$ NLNG should thus consider the globalised increasingly advancing process and practice of checkmating complicity in human and environmental rights abuses by companies, especially multinational oil and gas companies (MNOCs) operating in the oil-rich Niger Delta region. ${ }^{4}$ NLNG should do so truly, conscientiously and in all ramifications of its operational processes and/or activities in its host communities in the Delta region and Nigeria at large, and thereby sustainably uphold its status as a world-class LNG company and leader of CSR, which is meticulously advancing globalised corporate voluntarism to complement the rule of law in Nigeria, ${ }^{5}$ in order to boost business sustainability and overall SD in the country.

\section{The Global Compact as a Soft Law Business Regulatory Mechanism}

The term 'soft law' has already been defined and described in the preceding study as denoting a wide variety of global and other international legal and regulatory instruments, which have persuasive effects in the domestic jurisdictions of sovereign states, rather than being out rightly (legally) binding in the spheres of these states. On this note, the previous study gives some examples of soft law as UN General Assembly [UNGA] declarations, recommendations and resolutions, bilateral and multilateral treaties, as well as voluntary resolutions, recommendations, codes of conduct, guidelines, norms and standards, which emanate from the international sphere. ${ }^{6}$ The study distinguishes soft law mechanisms from hard law instruments, which are obligatory modes of conduct that are outrightly binding on the parties to them and can thus be promptly and legally enforced against any of the parties. It explains that hard laws govern humans and society at large, within domestic jurisdictions of

\footnotetext{
NLNG, 'NLNG: Our CSR: Economic Empowerment' <http://nlng.com/Our-CSR/Pages/Economic-Empowerment-(YES,-micro,BVC).aspx>; NLNG, 'NLNG: Our CSR: Education'<http://nlng.com/Our-CSR/Pages/Education-.aspx>; NLNG, 'NLNG: Our CSR: Health' $<$ http://nlng.com/Our-CSR/Pages/Health.aspx>; NLNG, 'NLNG: Our CSR: NLNG University Support Scheme' <http://nlng.com/OurCSR/Pages/NLNG-University-Support-Programme.aspx>; NLNG, 'NLNG: Our CSR: Vendors Finance Scheme' <http://nlng.com/OurCSR/Pages/NLNG-Vendors-Finance-Scheme.aspx>; NLNG, 'NLNG: The Nigeria Prizes' <http://nlng.com/Our-CSR/Pages/The-NigeriaPrizes.aspx>; NLNG News, 'Nigeria takes first step in \$12billion LNG Expansion Plan (Bloomberg Report)' $<$ http://nlng.com/NIGNLNG/News.aspx?ID=27>; NLNG, NLNG: NLNG: Our Environment: NLNG and the Environment' $<$ http://www.nlng.com/Our-Environment/Pages/NLNG-and-Environment.aspx>all Accessed 7 February, 2020.

2 NLNG, 'NLNG: Our Company: Host Communities' (n72).

${ }^{3}$ J. Osai, 'Shell as Agama Lizard: A Niger Deltan Likens Shell's False Public Relations in Nigeria to 'Agama' Lizard, A Self-Praising Creature' $<$ http://oloibiri.blogspot.com/2004/10/shell-as-agama-lizard.html> Accessed 7 February, 2020; K. Gilblom, 'Shell Tries to Come Clean on Its Dirty Past in Nigeria: As the company moves away from oil, it can't shake its years operating in the pollution- and graft-ridden nation.' $<$ https://www.bloomberg.com/news/articles/2018-09-28/shell-tries-to-come-clean-on-its-dirty-past-in-nigeria> Accessed 7 February, 2020; A. Manirabona and Y. V. Cárdenas, Extractive Industries and Human Rights in an Era of Global Justice: New Ways of Resolving and Preventing Conflicts (LexisNexis Canada 2019); M. Bavinck et al (eds), Conflicts Over Natural Resources in the Global South: Conceptual Approaches (CRC Press 2014); J. Rexler, 'Beyond the Oil Curse: Shell, State Power, and Environmental Regulation in the Niger Delta' [2010] 12 (1) Stanford Journal of International Relations, 26-31; B. Maiangwa and D. E. Agbiboa, 'Oil Multinational Corporations, Environmental Irresponsibility and Turbulent Peace in the Niger Delta' [2013] 48 (2) Africa Spectrum, 71-83; O. Oluduro, 'Oil Exploitation and Human Rights Violations in Nigeria's Oil Producing Communities' [2012] 25 (2) Afrika Focus, 160-166; E. Blanco and J. Razzaque, Globalisation and Natural Resources Law: Challenges, Key Issues and Perspectives (Edward Elgar Publishing 2011); The UN Interagency Framework Team for Preventive Action and The Poverty Group of Bureau for Development Policy (BDP), UNDP, Conflict Prevention in Resource-Rich Economies: Toolkit and Guidance for Preventing and Managing Land and Natural Resources Conflict (UNDP 2011).

${ }^{4}$ Wiwa $v$ Shell Petroleum Development Company of Nigeria Limited (SPDC), 04 Civ. 2665, (SDNY); Wiwa et al. v Royal Dutch Petroleum Company, et al., Case No. 96 Civ. 8386 (KMW) (HBP) (Southern District of New York [SDNY]); Ken Wiwa et al. v Brian Anderson et al., Case No. 01 Civ. 1909 (KMV) (HBP) (SDNY); Kiobel v Royal Dutch Petroleum Company [2013] US 133 S Ct. 1659.

${ }^{5}$ R. Cui, Oil Multinationals in Nigeria Human Rights, Sustainable Development and the Law (Anchor Academic Publishing 2015).

${ }^{6}$ P. Westerrman et al (eds), Legal Validity of Soft Law (Springer International Publishing 2018); A. T. Guzman and T. L. Meyer, 'International Soft Law' [2010] 2 (1) The Journal of Legal Analysis, 171-225; J. B. Skjærseth et al, 'Soft Law, Hard Law, and Effective Implementation of International Environmental Norms' [2006] 6 (3) Global Environmental Politics, 104-120; U. Etemire, 'Reflections on the Role of International Custom and Soft Law in Environmental Protection' [2016] 1 (1) UNIPORT Journal of Public Law, 60-61; European Center For Constitutional and Human Rights (ECCHR), 'Term Hard Law/Soft Law'<https://www.ecchr.eu/en/glossary/hard-law-soft-law/> Accessed 7 February, 2020; E. T. Bristol-Alagbariya, Petroleum Development \& the Environment in Rivers State Nigeria: Fallouts of the UNEP Report on Ogoniland, Environmental Regulatory Standards \& Sustainable Development Laws \& Practices (LAP LAMBERT Academic Publishing 2018).
} 
sovereign states, whereas soft laws emanate from and mainly exist within the entire global arena and other international spheres (outside domestic jurisdiction of sovereign states).

The origin of the Global Compact, including the mission of the Compact, as herein precisely explained within the context of its aim and vision, as well as how the companies participating at the Compact are voluntarily applying the ten principles of the Compact in the course of their operations, demonstrate that the Compact is a soft law mechanism regulating the operations of companies to advance corporate responsibility towards business sustainability and SD. Moreover, given that the soft law regulatory mechanisms of the Global Compact are increasingly spurring companies to enlist to participate at the Compact to take greater steps towards business sustainability and SD wherever they operate around the globe, it may be stated that these companies are increasingly considering themselves to be voluntarily bound by the Compact. So far indeed, in about two decades of its existence, well over 10,000 companies from over 160 countries have enlisted into the Global Compact and thereby voluntarily abiding by, as well as practising the principles, values and other aspects of the framework of the Compact to advance corporate responsibility towards business sustainability and SD around the globe. ${ }^{1}$

It may therefore be asserted that in the ongoing era of SD, the UN Global Compact is being transformed from a mere persuasive device (soft law mechanism) into a concrete obligatory framework (a hard law instrument), governing the operations of the companies listed into the Compact. There is however a need, for good governance (GG), to strengthen corporate responsibility, ${ }^{2}$ particularly in developing countries plagued by bad governance, given that GG and SD are indivisible and intertwined. ${ }^{3}$

\section{Conclusion}

So far, this study has demonstrated that the UN Global Compact, founded by the Seventh UN Secretary-General, Kofi Annan), was established about twenty years ago, in July 2000, sequel to ongoing global efforts, being spearheaded and midwifed by the UN, to advance corporate responsibility for the promotion of business sustainability and SD. The Compact is increasingly generating a global consensus on the role of business in society, as the study reveals that the Compact is a classic example of corporate citizenship, which is taking corporate responsibility from the fringes to the mainstream and uniting business towards a better, fairer, kinder, more just, sustainable and peaceful world on Planet Earth, based on long-term business sustainability strategies. These strategies include the values of the Compact upon which its prevailing ten principles in the areas of human rights, labour, the environment and anti-corruption evolved. These principles demonstrate that corporate sustainability starts with a company's SD-oriented value system and consequently its principled approach to doing business.

In spite of certain identified challenges associated with the Global Compact, it remains a world-wide leading inspirational guide on the ten principles that companies enlisted into the Compact framework are, at a minimum, required to operate, in ways that align their operations to conform to, and to promote and actualise developmental partnerships arising therefrom towards business sustainability and overall SD.

The thirteen examples of good CSR performances-in-action, discussed in this study and numerous other exemplary cases of CSR around the world indicate that companies are voluntarily promoting the principles, values and other initiatives of the Global Compact and thereby advancing corporate citizenship to boost business sustainability, environmental protection and partnerships towards overall SD. So, many companies participating at the Global Compact are advancing corporate social voluntarism (as a soft law mechanism) and gradually transforming same into social responsibility obligatory (hard law) practices, in the course of their operations to enhance business sustainability initiatives, such as environmental protection, human wellbeing, and sustainable community development (SCD) and overall SD around the globe.

The UN Global Compact is certainly a dynamic global benchmark on corporate citizenship, based on responsible, transparent, accountable and progressively consistent voluntary self-assessment and improvement of companies, towards business sustainability and overall SD. We therefore recommend that more and more companies (businesses) should enlist to participate at the Global Compact, while urging sovereign states, especially

\footnotetext{
${ }^{1}$ Homepage of the UN Global Compact'10,453 Companies, 161 Countries, 77, 516 Public Reports' <https://www.unglobalcompact.org/>; UN Global Compact, UN Global Compact: Participation: See Who's Involved: 1,200+ Signatories on Over 160 Countries, both Developed and Developing, Representing Nearly Every Sector and Size'<https:/www.unglobalcompact.org/participation>; UN Global Compact, UN Global Compact: Participation: Explore our Participants: See List of Our Participants' $<$ https://www.unglobalcompact.org/interactive $>$ all Accessed 7 February, 2020

${ }^{2}$ Paragraphs 27 and 29, Johannesburg Declaration on SD, 2002, on the limits of CSR and the regulatory duties and responsibilities of government; E. T. Bristol-Alagbariya, Participation in Petroleum Development: Towards Sustainable Community Development in the Niger Delta (Centre for Energy, Petroleum \& Mineral Law \& Policy [CEPMLP]/Dundee University Press [DUP] 2010), 16-17 and 331; T. Edoh and T. Wuam (eds), Democracy, Leadership And Accountability in Post-Colonial Africa: Challenges And Possibilities: Essays in Honour of Professor Akase Paul Sorkaa (Aboki Publishers 2009); T Wuam and T. N. Sunday (eds), Governance and Economic Development in the Fourth Republic (Aboki Publishers 2010).

${ }^{3}$ WCED (n1), x-23, particularly 9; K. Annan, 'International Conference on Governance for Sustainable Growth and Equity', New York, 2830 July, 1997 <http://www.pogar.org/publications/other/undp/governance/annan-address-e.pdf> Accessed 7 February, 2020; G. Ayre and R. Callway (eds), Governance for Sustainable Development: A Foundation for the Future (Earthscan 2005); H. Clark, The Importance of Governance for Sustainable Development (The Institute of Southeast Asian Studies [ISEAS] Publishing 2012).
} 
developing countries, to strengthen governance, by enthroning GG, to encourage and persuade companies to advance broader societal goals. By continuously improving their ability and performances in terms of implementing their social responsibilities, companies would increasingly contribute to achieve greater public good and thereby progressively enhance the wellbeing of their stakeholders, humanity and society at large (within Planet Earth).

\section{References}

Aaron K. K., Corporate Social Responsibility Performance in the Niger Delta: Beyond Two Constitutive Orthodoxies' [2011] 21 (6) Development in Practice, 779-789.

Ayre G. and Callway R. (eds), Governance for Sustainable Development: A Foundation for the Future (Earthscan 2005).

Barrera-Hernandez L., Barton B., Godden L., Lucas A., and Ronne A. (eds), Sharing the Costs and Benefits of Energy and Resources Activity: Legal Change and Impact on Communities (Oxford University Press 2016).

Blanco E. and Razzaque J., Globalisation and Natural Resources Law: Challenges, Key Issues and Perspectives (Edward Elgar Publishing 2011).

Bavinck M., Pellegrini L. and Mostert E. (eds), Conflicts Over Natural Resources in the Global South: Conceptual Approaches (CRC Press 2014).

Black L., The Social Licence to Operate: Your Management Framework for Complex Times (Routledge 2017).

Bristol-Alagbariya E. T., Petroleum Development \& the Environment in Rivers State Nigeria: Fallouts of the UNEP Report on Ogoniland, Environmental Regulatory Standards \& Sustainable Development Laws \& Practices (LAP LAMBERT Academic Publishing 2018).

Bristol-Alagbariya E. T., Participation in Petroleum Development: Towards Sustainable Community Development in the Niger Delta (Centre for Energy, Petroleum \& Mineral Law \& Policy [CEPMLP]/Dundee University Press [DUP] 2010), 16-17 and 331.

Campese J., Sunderland T., Greiber T. and Oviedo G. (eds), Rights-based Approaches Exploring Issues and Opportunities for Conservation (Center for International Forestry Research [CIFOR] and IUCN) 2009.

Clark H., The Importance of Governance for Sustainable Development (The Institute of Southeast Asian Studies [ISEAS] Publishing 2012).

Cooper R. H. and Kohler J. V. (eds), Responsibility to Protect: The Global Moral Compact for the 21st Century (Palgrave Macmillan 2009).

Douglas O. and Okonta I., Where Vultures Feast: Shell, Human Rights, and Oil in the Niger Delta (Sierra Club 2001).

Edoh T. and Wuam T. (eds), Democracy, Leadership And Accountability in Post-Colonial Africa: Challenges And Possibilities: Essays in Honour of Professor Akase Paul Sorkaa (Aboki Publishers 2009).

Etemire U., 'Reflections on the Role of International Custom and Soft Law in Environmental Protection' [2016] 1 (1) UNIPORT Journal of Public Law, 60-61.

Fussler C., Cramer A. and van der Vegt S. (eds), Raising the Bar: Creating Value with the UN Global Compact (Routledge 2017).

Guzman A. T. and Meyer T. L., 'International Soft Law' [2010] 2 (1) The Journal of Legal Analysis, 171-225.

Jonker J. and de Witte M. (eds), The Challenge of Organizing and Implementing Corporate Social Responsibility (Palgrave Macmillan 2006).

Lawrence J. T. and Beamish P. W (eds), Globally Responsible Leadership: Managing According to the UN Global Compact (SAGE Publications 2013).

Maiangwa B. and Agbiboa D. E., 'Oil Multinational Corporations, Environmental Irresponsibility and Turbulent Peace in the Niger Delta' [2013] 48 (2) Africa Spectrum, 71-83.

Manirabona A. and Cárdenas Y. V., Extractive Industries and Human Rights in an Era of Global Justice: New Ways of Resolving and Preventing Conflicts (LexisNexis Canada 2019).

Morrison J., International Business Challenges in a Changing World (Springer Nature 2019).

Morrison J., The Social Licence: How to Keep Your Organization Legitimate (Palgrave Macmillan 2014).

Oluduro O., 'Oil Exploitation and Human Rights Violations in Nigeria's Oil Producing Communities' [2012] 25 (2) Afrika Focus, 160-166.

Rasche A. and Kell G. (ed), The United Nations Global Compact: Achievements, Trends and Challenges (Cambridge University Press 2010).

Rexler J., 'Beyond the Oil Curse: Shell, State Power, and Environmental Regulation in the Niger Delta' [2010] 12 (1) Stanford Journal of International Relations, 26-31.

Sidaway R., Resolving Environmental Disputes from Conflicts to Consensus (Earthscan 2013).

Stott L. (ed), Shaping Sustainable Change: The Role of Partnership Brokering in Optimising Collaborative Action (Routledge 2019).

Skjærseth J. B., Stokke O. S. and Wettestad J., 'Soft Law, Hard Law, and Effective Implementation of International 
Environmental Norms' [2006] 6 (3) Global Environmental Politics, 104-120.

The UN Interagency Framework Team for Preventive Action and The Poverty Group of Bureau for Development Policy (BDP), UNDP, Conflict Prevention in Resource-Rich Economies: Toolkit and Guidance for Preventing and Managing Land and Natural Resources Conflict (UNDP 2011).

UN, United Nations Global Compact Inspirational Guide: Human Rights, Labour, Environment, Anti-corruption, Partnerships for Development (UN 2008).

UNEP, Healthy Environment, Healthy People (UNEP 2016).

Westerman P., Hage J., Kirste S. and Mackor A. R. (eds), Legal Validity and Soft Law (Springer International Publishing AG 2018).

Williams O. F. (ed), Sustainable Development: The UN Millennium Development Goals, the UN Global Compact, and the Common Good (University of Notre Dame Press 2014).

Williams O. F., 'The UN Global Compact: The Challenge and the Promise' [2004] 14 (4) Business Ethics Quarterly, 755-774.

Wilson E., 'What is Social Licence to Operate? Local Perceptions of Oil and Gas Projects in Russia's Komi Republic and Sakhalin Island'[2016] The Extractive Industries and Society, 3 (1) 73-81.

The World Commission on Environment and Development (WCED), Our Common Future (Oxford University Press 1987), $\mathrm{x}-23,40$ and 43.

Wuam T. and Sunday T. N. (eds), Governance and Economic Development in the Fourth Republic (Aboki Publishers 2010). 